\title{
Effects of Effluent Discharge on Man and Soil Ecosystem in Calabar, South Southern Nigeria
}

\author{
${ }^{1} \mathrm{UMOH}, \mathrm{JD} ;{ }^{2} \mathrm{IKWA}, \mathrm{LOE} ;{ }^{* 3} \mathrm{UCHENDU,} \mathrm{UI}$ \\ ${ }^{1,3}$ Department of Environmental Management and Toxicology, ${ }^{2}$ Department of Forestry and Environmental Management, Michael Okpara \\ University of Agriculture, Umudike, Imo State, Nigeria \\ *Corresponding Author Email: udouche@yahoo.com, obiaikwa@gmail.com,Tel: 08034417690
}

\begin{abstract}
The impact of Flour Mill Effluent (FME) on soil physicochemical properties at Ekorinim in Calabar, Cross River State, Nigeria, were analyzed at the depths of $0-15 \mathrm{~cm}$ and $15-30 \mathrm{~cm}$. Conventional analytical methods were employed for the determination of these physicochemical parameters. The results of the physicochemical analysis showed that the Bulk density in polluted soil ranged from the mean SD $1.23 \pm 1.45 \mathrm{mg} / \mathrm{dm}^{3}$ and the mean value of non-contaminated soil was 7.4.1 $\pm 1.20\left(\mathrm{mg} / \mathrm{dm}^{3}\right)$, the porosity of polluted soil $0.48 \pm 0.55\left(\mathrm{mg} / \mathrm{dm}^{3}\right)$ and non-polluted soil $0.48 \pm 0.33 \mathrm{mg} / \mathrm{dm}^{3}$. The $\mathrm{pH}$ values in all the sites ranged from 5.01 to 5.70, indicating acidity of the soils. The Soil Organic Carbon concentration values ranged from of $0.57 \%-2.39 \%$ in both polluted and non-polluted soils, indicating presence of some organic matter and microbiological activities in the soil samples. The Electrical Conductivity of contaminated soil is extremely saline, while the one of non-polluted soil is very saline indicating significant presence of some soluble inorganic salts in soils studied. Minerals such as Nitrogen, Phosphorus and Potassium recorded highest concentration in soil with effluent discharged. CEC in polluted and non-polluted soil have mean standard deviation of $2.15 \pm 0.74 \mathrm{cmol} \mathrm{kg-}{ }^{1}, 1.79$ $\pm 0.74 \mathrm{cmol} \mathrm{kg}^{-1}$ respectively, lower than the critical limit of $<0.6 \mathrm{cmol} \mathrm{kg}^{-1}$ which is low in nature. Significant differences in the levels of manganese, iron, chromium, magnesium, nitrate, clay and sand, temperature, conductivity $\mathrm{pH}$, and $\mathrm{CEC}$ across the different Sampling locations and the topsoil of Flour Mill Effluent were observed (ANOVA, $p \leq 0.05$ ) Overal results indicated that, Flour Mill Effluent can add nutrients to the soils if properly harnessed to eliminate heavy metals which constitute a major health risk to the local population through pollution.
\end{abstract}

DOI: $\underline{\text { https://dx.doi.org/10.4314/jasem.v23i6.10 }}$

Copyright: Copyright (C) 2019 Umoh et al. This is an open access article distributed under the Creative Commons Attribution License (CCL), which permits unrestricted use, distribution, and reproduction in any medium, provided the original work is properly cited.

Dates: Received: 27 April 2019; Revised: 22 May 2019; Accepted 11 June 2019

Keyword: Flour Mill Effluents, Soil Physicochemical properties, Pollution, heavy metals

Industrial wastes are major sources of pollution in our environments and require on-site treatment before discharge into the ecosystem (Khopkar, 2007). Soil and the environment are under tremendous pressure due to industrial expansion and discharge of effluents. In recent decades, environment and its associated problems have assumed a place of prominence in social, political, economic and scientific discourse. This development arises from the myriad of environmental problems of various complexions and intensities witnessed across the length and breadth of Nigeria (Akhionbare, 2009). In Calabar, there has been remarkable agricultural, industrial and economic growth especially in the last few years. Yet soil pollution and its associated problems has not been adequately checked; and environmental policies are rarely enforced especially in the industrial sector. Moreover, Production activities of these industries has increased in Calabar since early 2000, with such industries as cement factory, flour mill industries, petrochemicals, paint industries; pharmaceuticals, fast foods and garments industry without adequate monitoring of effluent discharge in the environment. The issues go deeper as it raises serious concern when human life is being threatened. Unfortunately, data on such treated effluent before discharges in the environment is scanty, and unavailable in most cases.
Soil is not only a medium for plants growth or waste disposal but also a transmitter of many pollutants to surface water, ground water, atmosphere and food. Soil pollution may threaten human health not only through its effect on hygiene quality of food and drinking water, but also through its effect on air quality. Little attention has been paid to soil pollution compared to food in the past (Khopker, 2007) More recently, however, the impact of soil pollution on soil functions and the biosphere has been increasingly emphasized by the government, environmental protection agencies and the public (Ubuoh, 2012). A knowledge of the level and distribution of heavy metals in soils can play a key role inland use planning, the designing of control strategies to achieve a better environmental quality as well as a key to effective management of soil quality especially in rapidly growing area such as Cross River State.

In as much as soil plays a major role in the attenuation and removal of different pollutants contained in the effluent, there is therefore a need for a healthy soil so as to play its role. Based on this observed problem of industrial effluent discharged into the soil, the study then focusses on the impact of Flour Mill Effluent (FME) on the soil environmental sustainability as regard to waste treatment in the study area. 


\section{MATERIALS AND METHODS}

Study Area: This study was carried out in Ekorinim Calabar Municipality, Calabar Cross River State in South Eastern Nigeria. Calabar Municipality lies between latitude $04^{\circ} 15^{\prime} \mathrm{N}$ and longitude $8^{\circ} 25^{\prime} \mathrm{E}$ (hand held Global positioning system-GPS Receiver Garmin Ltd Kansas USA). In the North, the Municipality is bounded by Odukpani Local Government Area, in the North-East by the great Kwa River. Its Southern shores are bounded by the Calabar River and Calabar South Local Government Area. It has an area of 331.551 square kilometres. (Calabar, 2011).

Soil Sample Analysis: Soil pH was determined in 1:2.5 soil/water suspension using $\mathrm{pH}$-meter as described by Rowell (1994). Extractable organic carbon (EC) was determined in 1:5 soil/water suspension by an electrical conductivity meter as explained by Rhoades (1982). Determination of Soil moisture content was carried out by the gravimetric method as used by Kara and Bolat (2008). Soil organic matter was determined using the Walkley-Black wet oxidation method (Walkley and Black, 1934). Total nitrogen was determined by the Kjeldahl method as given by Bremner and Mulvaney (1982). Available phosphorus (AVP) was determined by weighing $1 \mathrm{~g}$ of sample and adding phosphorus extracting solutions as explained by Bray and Weil (1996).

The exchangeable bases were extracted with neutral 1 $\mathrm{ml}$ of $\mathrm{NH}_{4} \mathrm{Ac}$ at a $\mathrm{pH}$ of 7 . The potassium and sodium in the extract was determined by flame photometry while calcium and magnesium were obtained by versenate EDTA titration as outlined by Jackson (1962). Determination of $\mathrm{CaCO}_{3}$ content was done by the Scheibler calcimeter method of Allison and Moodie (1965). Total exchangeable bases were determined by adding $\mathrm{Ca}, \mathrm{Mg}, \mathrm{Na}$ and $\mathrm{K}$. Percentage base saturation was determined by dividing total exchangeable bases by effective cation exchange capacity (ECEC), multiplied by 100 . Heavy metal contents were extracted from the soil samples by digesting the samples with a mixture of nitric and perchloric acid as described by Barnhisel and Bertsch (1982).

\section{RESULTS AND DISCUSSION}

Table 1 summarizes contaminated soil from flour mill effluent and uncontaminated soil from control site using total, mean and standard deviation and the results are then compared with unified standard for soil quality for full understanding of the environmental implications.

The standards are World Health Organization WHO, 2006, Federal Ministry of Environment FMEV, 2006 and National Environmental Standards and Regulations Enforcement Agency, NESREA, 2009.

Soil $\mathrm{pH}$ is an important soil property, having great effects on solute concentration and absorption in soil(Ubuoh et. al., 2013).From the summary of soil samples from contaminated and uncontaminated soils at the depth of $0-15 \mathrm{~cm}$ in table 1 , it was observed that soil $\mathrm{pH}$ of the contaminated soil recorded mean value of $\mathrm{pH} 5.7$ with the SD of 1.203, and uncontaminated soil had mean value of $\mathrm{pH} 5.01$ with the SD of 0.99 signifying that the both soils are acidic, in which the acidity from contaminated soil is suspected to come from effluent.

The $\mathrm{pH}$ values of all the soils samples analysed from the two sites are close. In both samples, the contaminated soil $\mathrm{pH}$ increased with the application of effluent as compared to uncontaminated soil. The increase of soil $\mathrm{pH}$ is due to addition of various soluble salts in industrial effluent also reported (Ubuoh, 2012). While working on soil characteristics affected by long term application of sewage waste water. These values are below the range with the values reported by Ikwa et al., (2008), but higher than the values reported by Uzoije and Onunkwo, (2011) who reported the $\mathrm{pH}$ values of all the soil samples analysed from the two towns were close, ranging from 7.01 to 7.99.

The soil $\mathrm{pH}$ in both sites were highly acidic which negate the $\mathrm{pH} 6.5 \mathrm{WHO} / \mathrm{FMENV}$ Standards for soil quality. It is also observed that the mean value of bulk density in contaminated soil recorded $1.23(\mathrm{mg} / \mathrm{kg})$ with SD of 0.125 and the mean value of uncontaminated soil shown $5.035(\mathrm{mg} / \mathrm{kg})$ with SD of 12.288 is greater than contaminated soil at the depth of $0-15 \mathrm{~cm}$ within the point surface.

The result conforms with the finding of (Uwah et al.,2012) who explained that soils with well-developed structure will have low density values whereas poorly structured soils will have high bulk density values approaching $1.8 \mathrm{mg} / \mathrm{m}^{3}$, or greater. It is observed that the mean value of Phosphorus in contaminated and uncontaminated soils are $0.76,0.84$ with SD of 0.47 and 0.75 respectively, with control having the highest value. Phosphorus can be added to the environment by man's activities as point source discharges or as nonpoint source runoff. Typical sources include industrial and municipal wastewater discharges or runoff from agricultural lands or urban areas (Oviasogie and Ofomaja, 2007).

In acidic soils, much of the $\mathrm{P}$ become fixed up by reaction with iron $\left(\mathrm{Fe}^{3+}\right)$, Aluminium $\left(\mathrm{Al}^{3+}\right)$, and Manganese to form insoluble compounds (Ubuoh et al., 2013). 
Table 1: Contaminated and uncontaminated Soil samples from plough surface

\begin{tabular}{|c|c|c|c|c|c|c|c|c|}
\hline \multirow[t]{2}{*}{ Parameter3 } & \multicolumn{3}{|c|}{$\begin{array}{l}\text { Contaminated soil } \\
\text { Point Surface }(0-15 \mathrm{~cm})\end{array}$} & \multicolumn{3}{|c|}{$\begin{array}{l}\text { Uncontaminated soil } \\
\text { Point Surface }(0-15 \mathrm{~cm})\end{array}$} & \multirow{2}{*}{$\begin{array}{l}\text { WHO; } \\
\text { FMEV } \\
2006\end{array}$} & \multirow[t]{2}{*}{$\begin{array}{l}\text { NESRFA } \\
2009\end{array}$} \\
\hline & Total & Mean & $\begin{array}{l}\text { Standard } \\
\text { deviation }\end{array}$ & Total & Mean & $\begin{array}{l}\text { Standard } \\
\text { deviation }\end{array}$ & & \\
\hline $\mathrm{pH}$ & 57 & 5.7 & 1.203698 & 50.1 & 5.01 & 0.886253 & 6.5 & $6-9$ \\
\hline Temperature $\left({ }^{0} \mathrm{C}\right)$ & 243.3 & 27.03 & 0.648074 & 232.4 & 23.24 & 2.40518 & $20-30$ & $<3 a$ \\
\hline Conductivity & 219 & 21.9 & 12.29679 & 15.52 & 15.52 & 6.094952 & 100 & NS \\
\hline Potassium $\left(\mathrm{mg} / \mathrm{dm}^{3}\right)$ & 7236 & 723.6 & 92.56973 & 6700 & 670 & 106.5531 & $>100$ & NS \\
\hline Calcium $\left(\mathrm{mg} / \mathrm{dm}^{3}\right)$ & 340 & 34 & 17.76388 & 278 & 27.8 & 15.54063 & 250 & NS \\
\hline Magnegium $\left(\mathrm{mg} / \mathrm{dm}^{3}\right)$ & 7115 & 711.5 & 67.00124 & 6447 & 644.7 & 65.76059 & $>100$ & NS \\
\hline Manganege ( $\left.\mathrm{mg} / \mathrm{dm}^{3}\right)$ & 14.8 & 1.48 & 1.150652 & 10.9 & 1.09 & 0.943339 & 250 & NS \\
\hline Sodium $\left(\mathrm{mg} / \mathrm{dm}^{3}\right)$ & 28.18 & 2.818 & 0.435867 & 23.138 & 2.313 & 0.849303 & $<$ & 200 \\
\hline $\operatorname{Zinc}\left(\mathrm{mg}^{\left.\mathrm{d} \mathrm{dm}^{3}\right)}\right.$ & 10.30 & 1.030 & 0.881556 & 8.649 & 0.864 & 0.905662 & $<1.0$ & 421 \\
\hline Copper $(\mathrm{mg} / \mathrm{kg})$ & 10.99 & 1.099 & 0.378196 & 9.379 & 0.937 & 0.446629 & 1.0 & NS \\
\hline Phosphate $\left(\mathrm{mg} / \mathrm{dm}^{3}\right)$ & 23.3 & 2.33 & 1.428325 & 15.1 & 1.51 & 1.00161 & & NS \\
\hline Nitrate $\left(\mathrm{mg} / \mathrm{dm}^{3}\right)$ & 1520. & 152.0 & 24.65763 & 1202 & 120.2 & 66.24468 & 20 & NS \\
\hline Nitrate-nitro(mg/ $\left.\mathrm{dm}^{3}\right)$ & 342.2 & 34.22 & 4.262706 & 520.8 & 52.08 & 41.62643 & & 10 \\
\hline Ammonia $\left(\mathrm{mg} / \mathrm{dm}^{3}\right)$ & 36.22 & 3.622 & 1.644079 & 73.52 & 7.352 & 9.563436 & & 30 \\
\hline Nitrite $\left(\mathrm{mg} / \mathrm{dm}^{3}\right)$ & 443 & 44.3 & 7.227263 & 307.2 & 30.72 & 13.96765 & & NS \\
\hline Nitrite-nitrogen $\left(\mathrm{mg} / \mathrm{dm}^{3}\right)$ & 135 & 13.5 & 2.12132 & 88.2 & 8.82 & 4.27546 & & NS \\
\hline Bulk density (\%) & 12.3 & 1.23 & 0.125167 & 50.3 & 5.03 & 12.28758 & & NS \\
\hline Clay $(\%)$ & 435 & 43.5 & 13.34375 & 347.2 & 34.72 & 14.71 & & NS \\
\hline Sand $(\%)$ & 433 & 43.3 & 13.08137 & 372.2 & 37.22 & 19.15654 & & NS \\
\hline Silt $(\%)$ & 132 & 13.2 & 7.828722 & 110.2 & 11.02 & 7.378919 & & NS \\
\hline Porosity (\%) & 4.8 & 0.48 & 0.063246 & 3.01 & 0.301 & 0.104398 & & NS \\
\hline Organic carbon (\%) & 23.9 & 2.39 & 1.420837 & 15.8 & 1.58 & 1.214542 & & NS \\
\hline CEC & 21.48 & 2.148 & 2.354158 & 17.92 & 1.792 & 2.087469 & & NS \\
\hline
\end{tabular}

WHO: World Health Organization; FMEV: Federal Ministry of Environment; NESREA: National Environmental Standards and Regulatory Enforcement Agency

The results of particle sizes shows that clay, sand and silt have mean values of $43.5 \%, 43.25 \%, 13.2 \%$ with SD of $13.4,13.08,7.83$, with porosity having the mean value of $0.48\left(\mathrm{~g} / \mathrm{cm}^{3}\right)$ with SD of 0.06 in contaminated soil while uncontaminated soil has clay, sand and silt mean values of $34.47 \%, 37.22 \%$ and $11.02 \%$ with SD of $14.71,19.16$ and 7.38 , with the mean porosity 0.30 $\left(\mathrm{g} / \mathrm{cm}^{3}\right)$ and SD of 0.10 nitrate in contaminated and uncontaminated soils recorded mean value of $152.09 \mathrm{mg} / \mathrm{dm}^{3} 120.2 \mathrm{mg} / \mathrm{kg}$ with standards of 24.66 and 66.24 with soil with effluent having higher concentration than control site within point surface respectively. Both sites have nitrate concentrations in the soil above the $20 \mathrm{mg} / \mathrm{dm}^{3}$ WHO/ FMENV standards for soil quality. Indicating that the soil polluted by effluent is done by industrial activity, while control is geogenic, stressful growing conditions often result in high concentrations of nitrates in plant tissue. When feeding animal forages containing toxic levels of nitrates, poor productivity or death may occur (Ikwa et al., 2013). CEC in polluted and unpolluted soil have mean standard deviation of $2.148 \pm 2.354$ $\left(\mathrm{cmol} \mathrm{kg}^{-1}\right), 1.792 \pm 2.087 \mathrm{cmol} \mathrm{kg}^{-1}$ ) lower than the critical limit of $<0.6 \mathrm{cmol} \mathrm{kg}^{-1}$ ) which is low in nature. The CEC of a soil is influenced by a number of factors. Organic matter (\% OM) for example, retains very high ionic forces which can increase a soil's ionic exchange capacity (Oorts et al.,2003) shows that contaminated and uncontaminated soils have mean values of 2.5 cmol kg${ }^{-1}, 1.8 \mathrm{cmol} \mathrm{kg}^{-1}$ and SD of 2.4 and 2.1 respectively with soil with effluent having higher CEC than control site. The result is in line with the findings of (Ubuoh et al., 2013) who observed that, the higher the CEC the more clay or organic matter present in the soil.

Conclusion: The result obtained from this study revealed contaminated soil recorded low bulk density than control soil due to increase in effluent discharged. Clay and sand in polluted soil were greater in percentage than silt. Polluted soil was less acidic but above the WHO standard leading to mobility of heavy metals in the soil. Except Nitrogen in control, Potassium and Phosphate were found to be more in soil with effluent than control which could aid agriculture. The organic Carbon of the soil increased with effluent. CEC was higher in polluted soil than control.

\section{REFERENCES}

Akhionbare, SMO (2009). The Environment: Concepts, Issues and Pollution. MSc Computer Press, Nnewi, Nigeria.

Bray, NC; Weil, RR (1996). The Nature and Properties of Soils. 12th Edition, Prentice Hall, New Jersey.

Calabar, (2011) Retrieved from http: www.crossriverstate.gov.ngon 3/5/2012 Weather Base: Historical Weather for Calabar, Weather Base. (2011). Retrieved on November 24, 2012. Calabar

FEPA, (1991). Standard Range of Heavy Metals in Sediment Guidelines and Standard for 
Environmental Pollution Control in Nigeria 6: 70- 71.

Ikwa, OE; Ijeoma, K; Eke, V (2013). Impact of Liquid Effluent from Flour Mills on Physicochemical Properties of Soils of Calabar, Inter. J. Agric. Develop. 2(5): 10 .

Khopkar, SM (2007) Environmental Pollution Monitoring and Control. New Age International Publishers, New Delhi.

Oorts, K; Vanlauwe, B; Merckxa, R; (2003), Cation Exchange Capacities of Soil Organic Matter Fractions in A Ferric Lixisol with Different Organic Matter Inputs. Agric. Ecosystem. Environ. 100 (2):161-171.

Oviasogie, PO; Ofomaja, A. (2007). Available Mn, $\mathrm{Zn}, \mathrm{Fe}, \mathrm{Pb}$ and Physicochemical Changes Associated with Soil Receiving Cassava Mull Effluent. J. Chem. Soc. Nig. 32(1):69- 73

Ubuoh, EA; Akhionbare, WN; Oweremadu, E; Onifade, OA (2013). Characterization of Soil Quality in Erosion Prone Environment of Ukpor, Nnewi-South L.G.A. Of Anambra State, Nigeria. Inter. J. Adv. Appl. Sci. 2(1):1-8.
Ubuoh, EA. (2012). Verification of Vehicular Emitted Aerosol Components in Soil Biochemical Characteristics in Owerri West Local Government Area, Imo State, Nigeria. Inter. J. Adv. Appl. Sci. 1 (4):147-153.

Uwah, EI; Ndahi, NP; Ogugbuaj, VO (2009). Study of The Levels of Some Agricultural Pollutants in Soils and

Water Leaf (Talinum Triangulare) Obtained in Maiduguri, Nigeria. J. Appl. Sci. Environ. Sanit. 4(2): $71-78$.

Uzoije, AP; Onunkwo, AA (2011). Soil Quality Modelling of a Highly Acidic EutricTropofluvent Soil. International Journal of Soil Science 6: 164-175.

Walkey, A; Black, IA (1934). Protection and Improvement of Human Environment asan Instrument of Developing Countries. Calcutta: Vijoya Publishing House. 